\title{
Salvación y liberación en el pensamiento teológico de Leonardo Boff
}

\author{
Osmir Ramírez Trillos*
}

Recepción: 25 de agosto de 2018 • Aprobación: 21 de septiembre de 2018

\section{Resumen}

El artículo aborda la relación intrínseca entre salvación y liberación en el pensamiento del teólogo Leonardo Boff. Todo conocedor de la teología de la liberación sabrá que no es una característica propia de Boff relacionar salvación con liberación, sino que es la característica propia de la teología latinoamericana de la liberación. Nos concentraremos en uno de los mayores exponentes de esta característica teológica latinoamericana. La salvación como tema teológico puede tener infinidades de acercamientos epistemológicos. Por ello, al mirar la salvación desde el contexto de los países latinoamericanos, se producirá una reflexión específica para un auditorio particular, es decir, una salvación que busca la liberación del pobre. La teología y su reflexión sobre lo salvífico no debe quedarse en lo abstracto y especulativo, sino que debe tener un impacto social, chocar con lo político. “Cuando hoy hablamos de liberación significamos con esa expresión toda una tendencia y una encarnación concreta de nuestra fe" (Boff, 1987, p. 387).

Palabras clave: salvación, liberación, Reino de Dios, pobre.

* Artículo de investigación producto del proyecto de investigación como opción de grado para optar por el título de teóloga en la Fundación Universitaria Bautista. Fue presentado en el Primer Congreso Internacional de Teología Latinoamericana y del Caribe: 50 años de Medellín: Iglesia y signos de los tiempos, desarrollado en la Universidad Santo Tomás entre el 16 y el 19 de octubre de 2018. Citar como: Ramírez Trillos, O. (2019). Salvación y liberación en Leonardo Boff. Albertus Magnus, X(1), 33-50. Doi: https://doi.org/10.153322/5005413.5109.

* Fundación Universitaria Bautista, Colombia. Orcid: http://orcid.org/0000-0002-29175037. Correo electrónico: osmir08ramirez@gmail.com 


\title{
Salvation and liberation in the theological thought of Leonardo Boff
}

\begin{abstract}
The article addresses the intrinsic relationship between salvation and liberation in the thought of the theologian Leonardo Boff. Any expert of Liberation Theology will know that it is not in characteristic of Boff to relate salvation with liberation but it is the proper characteristic of Latin American theology of liberation. We focus on one of the greatest exponents of this Latin American theological characteristic. Salivation as a theological theme can have infinite epistemological approaches. Therefore, while looking at salvation from the context of Latin American countries, a specific reflection will be produced for a particular audience, that is, a salvation that seeks the liberation of the poor. Theology and its reflection on the salvation should not remain in the abstract and speculative, but should have a social impact, clash with the political. "When today we speak of liberation, by that expression we mean a whole tendency and concrete incarnation of our faith" (Boff, 1987, p. 387).
\end{abstract}

Keywords: salvation, liberation, God's Kingdom, poor.

\section{Salvação e libertação no pensamento teológico de Leonardo Boff}

\section{Resumo}

O artigo aborda a relação intrínseca entre salvação e libertação no pensamento do teólogo Leonardo Boff. Qualquer conhecedor da Teologia da Libertação saberá que não é característico de Boff relacionar salvação com libertação, mas que é a característica da teologia latino-americana da libertação. Nós nos concentramos em um dos maiores expoentes dessa característica teológica latino-americana. A salivação como tema teológico pode ter abordagens epistemológicas infinitas. Portanto, quando se olha para a salvação a partir do contexto dos países latino-americanos, uma reflexão específica será produzida para uma audiência particular, isto é, uma salvação que busque a libertação dos pobres. A teologia e sua reflexão sobre o salvífico não devem permanecer abstratas e especulativas, mas devem ter impacto social, colidir com o político. "Quando falamos hoje de libertação, entendemos por essa expressão toda uma tendência e encarnação concreta de nossa fé" (Boff, 1987, p. 387).

Palavras-chave: salvação, libertação, Reino de Deus, pobre. 


\section{Introducción}

Como se verá en este artículo, lo peculiar de la concepción de Leonardo Boff sobre la salvación está en la relación que hace con el término liberación. Sin embargo, esta relación no se da arbitrariamente, sino que se da en contexto, es decir, se filtra lo que se entiende por salvación a la luz de lo que ella le puede decir a un sujeto latinoamericano, ya que Boff está fuertemente influenciado por lo expresado, en lo referente al diálogo con la sociedad, en el Concilio Vaticano II (1962-1965). Al definirse lo que es liberación, se podrá comprender la relación que existe entre ella y salvación. Dicha relación está dada en lo que propone Boff por Reino de Dios. Es en el Reino de Dios donde liberación y salvación se perciben en lo universal y particular.

En primer lugar, se contextualizará la salvación para América Latina, a fin de elucidar que en parte los fundamentos teológicos como la salvación son comprehendidos en condición al contexto social y cultural; por esta razón, en la obra de Boff, salvación está inherentemente entrelazada con liberación social y del pecado. En segundo lugar, se abordará la relación que guarda el Reino de Dios con la salvación y con las liberaciones parciales de la historia humana. Como tercer punto, se explicará por qué el sujeto empobrecido, el "pobre", es importante para el Reino de Dios y, asimismo, se espera que el lector comprenda las razones por las cuales el pobre es de suma importancia para la teología latinoamericana de la liberación.

\section{Contextualización de la salvación}

La realidad salvífica no solo se puede expresar de distintas maneras, sino que debe ser contextualizada a la situación concreta humana; así cobrará sentido la salvación para cierta población, ya que es imposible salvarlos de algo que no esclaviza. Por esta razón, Leonardo Boff habla de la salvación en relación con la liberación de la esclavitud de los países latinoamericanos. La realidad de estos países es de esclavitud y de empobrecimiento, pero no porque estén en proceso al desarrollo, sino porque los países desarrollados dominan sobre los subdesarrollados para sostener su desarrollo. Es decir, los países ricos son ricos por empobrecer a los países del tercer mundo. Boff realiza el siguiente análisis social:

Se parte de la comprobación: el hecho brutal e insultante de las grandes mayorías de nuestro continente cristiano viviendo y muriendo en condiciones inhumanas de existencia. Subnutrición, mortalidad infantil, 
enfermedades endémicas, bajos ingresos, desempleo, falta de seguridad social, de higiene, de hospitales, de escuelas, de viviendas; en una palabra: el fenómeno de la insuficiencia de los bienes necesarios para una dignidad mínima de la persona. Tales son algunos de los indicadores que caracterizan la situación real de inmensas porciones de nuestros pueblos. (Boff, 1987, p. 16)

Considerando este contexto social, se comprende a cabalidad la razón que llevó a Boff a hablar de salvación como apertura a Dios por medio del prójimo. Por la cerrazón de ciertos países es que otros están en miseria. Aquellos países ricos también han reflexionado sobre Dios, pero, aun así, no se ha visto su apertura al prójimo. La cerrazón existe en cada país, incluso entre los empobrecidos. Boff, siguiendo a Johann Baptist Metz y Jürgen Moltmann, considera que la reflexión sobre la salvación no debe quedarse en lo abstracto, sino que debe tener un impacto social, chocar con lo político (Boff, 1987, p. 63).

Por tales circunstancias, cuando Leonardo Boff condiciona la apertura al prójimo como necesaria para la salvación, y cuando señala que la apertura a Dios no consiste en una práctica ritual, está criticando la praxis de fe de aquellos que están cerrados sobre sí mismos, pues en realidad afirman ser cristianos, pero su práctica vocifera lo contrario. "Cuando hoy hablamos de liberación significamos con esa expresión toda una tendencia y una encarnación concreta de nuestra fe [...] Nosotros tenemos una aguda sensibilidad para la dimensión social y estructural de la esclavitud y de la alienación humana" (Boff, 1987, p. 387). Apoyado en Karl Rahner, Boff considera que

el mandamiento del amor al prójimo no fue dado para que socialmente o privadamente nos soportemos o tengamos una vida más agradable, sino que es la proclamación de la preocupación de unos por otros y de la posibilidad de esta salvación de los unos por otros. (1975, p. 141)

La reflexión teológica de Boff está estrechamente vinculada con el contexto social de los países latinoamericanos, por ende, el principio teológico sobre la salvación adquirirá un nuevo componente; este componente es eminentemente histórico y social, es decir, la salvación necesariamente es liberación de las estructuras sociales de pecado. 


\section{Salvación y liberación}

Tanto la salvación como la liberación se relacionan en la praxis. Salvación es un concepto englobante de las liberaciones que se llevan a cabo en la praxis. Este concepto también engloba aquellas praxis de sujetos no cristianos pero que sí son liberadoras, por ende, salvación hace referencia a todas aquellas acciones que buscan liberación.

La praxis en sí misma, desde que sea una praxis verdaderamente liberadora, acarrea una densidad cristiana y salvífica. La salvación definitiva se mediatiza en liberaciones parciales históricas en todos los niveles de la realidad humana no solo en los teológicos. Eso permite a la fe cristiana identificar presencia evangélica y salvífica en aquellos movimientos y aquellas acciones que efectivamente liberan. No es el decir de la conciencia el criterio de autenticidad cristiana sino el ser de la realidad. Se trata aquí de plantear que no es la verdad que se piensa la que salva sino la verdad que se actúa y se verifica en una praxis.

De lo anterior se considera que la historia de la liberación del hombre es, simultáneamente, la historia de su salvación. La salvación no es otra cosa que liberación, pues salvación es lo que abarca todas las liberaciones, es decir, las liberaciones parciales son salvación universal, y esta se concretiza en las liberaciones parciales de la historia de la humanidad. "La salvación es un proceso universal dentro de la historia de los hombres [...] en una completa liberación de todas las alienaciones" (Boff, 1975, p. 91).

Se entiende, entonces, que afirme: "Dada la unidad de la historia de la salvación, podemos entonces afirmar que proceso de verdadera liberación es sinónimo de historia de la salvación. Auténtico crecimiento del mundo es también crecimiento del Reino de Dios" (Boff, 1975, p. 88). En consecuencia, el trasegar del hombre en busca de su salvación también es buscar su liberación, ya que las liberaciones parciales de una situación social y también de un corazón pecaminoso que se cierra en sí mismo son los caminos de la salvación. Cuando se obtiene una liberación concreta, lo que acontece es que el hombre está haciendo crecer el Reino de Dios en la historia humana.

\section{1. ¿Qué es liberación?}

Definición semántica de la palabra liberación.

LIBER-ACIÓN (acción), como la propia semántica sugiere, se constituye como la acción creadora de liber-tad. Es una palabra-proceso, palabra-acción, intencionalmente orientada a una praxis que libera DE 
y PARA. En efecto, la liberación supone un proceso de liberación DE un tipo de relacionamiento DE-pendiente, vivido como DE-primente y DE-pauperador. Clama por una DES-obstaculización IN-dependiente y AUTO-aseguradora del propio camino. (Boff, 1975, p. 44)

Se pasará a desarrollar lo que significa liberación de y para: ser libre de. El hombre [...] vive siempre situado dentro de su propia corporalidad, de su carga hereditaria de su familia, de su ambiente social, de la escala de valores de su mundo, etc. La situación es su límite y de ella depende. Libertad dentro de su circunstancia significa inicialmente independencia, ausencia de dependencia de eso o de aquello. No es una in-dependencia total porque un ser totalmente des-ligado del mundo y de todo no sería jamás el HOMBRE SER EN EL MUNDO. El hombre está siempre ligado a una situación. Por eso la libertad como in-dependencia quiere decir una libertad relativa, y solo en relación a esto o aquello (a una persona, a una ley, a un negocio) es independiente y libre. Para lo demás depende de sus necesidades básicas, de su ESTAR EN EL MUNDO. Un ser de total in-dependencia sería un ser de completa auto-determinación. En la figura de ese Ser las religiones se representaron el Absoluto y lo llamaron Dios. (Boff, 1975, p. 79)

Claramente se percibe la influencia de Martin Heidegger sobre Leonardo Boff, entonces, desde este filósofo se piensa que la razón de la imposibilidad de una in-dependencia total es, simplemente, que el hombre sea hombre y que esté en el mundo que le hace hombre. No se pretende decir que no hay liberación o independencia, solo se alude a la imposibilidad de que el hombre alcance un grado de totalidad por su propia cuenta, sin que esto le quite lo propio que lo constituye como hombre, pero sí se acepta la posibilidad de una independencia parcial. Cabe preguntar, según lo expuesto, ¿qué relación guarda lo parcial con lo total en cuanto a la liberación?

Ser libre para:

Alguien es in-dependiente y libre en la medida en que se independiza y se liberta de esto o de aquello. Ahora bien, solamente puede hacer eso el que se auto-determina y que, en alguna manera, se posee a sí mismo, asume su propio destino y se libera de determinaciones que vienen de otros. Libertad es, entonces, autodeterminación: poseerse a sí mismo y no ser poseído por otro. Lo específico de este tipo de libertad aparece, 
al analizarlo, en la palabra clave: AUTO-DETERMINACIÓN [...] lo que expresa el término AUTO: fuerza PROPIA y por eso libre por la cual el hombre coloca una determinación nueva (sobre-determinación) o asume, desecha, critica la determinación en la cual ya está. Libertad es poder AUTORREALIZARSE a sí mismo, dentro de su propia determinación existencial, social y política [...] En este sentido, el esclavo es un libre a partir del momento en que asumió libremente el ser esclavo, y en este sentido de libertad como autodeterminación solamente es esclavo porque no asume su determinación que está caracterizada por la ausencia de in-dependencia. Sin embargo, no siendo libre de, puede ser libre para. (Boff, 1975, pp. 79-80)

Ser libre para significa tener la posibilidad de autodeterminarse, para escoger o rechazar la dominación. Por ello, desde este punto de vista, el esclavo se percibe como tal porque no ha aceptado su condición, así que es esclavo por no aceptar ser esclavo, porque aceptar ser esclavo ya lo traslada a la esfera de la autodeterminación. Entonces ya no es esclavo propiamente, tal vez carece de libertad de, pero la libertad para está en su auge, pues él es libre para ser esclavo. Se entiende, por ende, que la libertad es un proceso en que cada momento el hombre puede autodeterminarse o esclavizarse.

La liberación del hombre no debe considerarse exclusivamente respecto de la liberación de opresiones socioeconómicas, de coyunturas políticas deprimentes, de dependencia de temas ideológicos globales, de comportamientos confeccionados por la sociedad, de compromisos frente a una tradición histórica, etc., sino también desde el punto de vista de la liberación del corazón del hombre. "El hombre en el proceso de la liberación necesita concientizarse de su opresión fundamental como ser humano pecador de la cual las servidumbres socio-económicas son variantes y ampliaciones" (Boff, 1975, p. 93).

La liberación como acción libera al hombre no solo de sino también para, es decir, que el hombre ya no es esclavo de-algo, sino que ahora es libre para-autodeterminarse. Se habla aquí de la liberación concreta del hombre, porque las liberaciones parciales o pequeñas son parte de la liberación universal y absoluta que está dirigida por Dios. Las liberaciones parciales del hombre no son ellas, en suma, la liberación total o la liberación de Dios; ellas son la anticipación y la esperanza en que tal liberación universal existe. "La liberación total propuesta por Dios pasa por el camino de liberaciones parciales; no es la suma de estas, sino que anticipa y prepara la liberación total" (Boff, 1987, p. 32). 


\subsection{Liberación concreta y salvación universal}

¿En Leonardo Boff cuáles son estas liberaciones concretas o pequeñas que anticipan la liberación universal?

Son los grupos de barrio, las comunidades eclesiales de base, movimientos de operarios y de jóvenes. Se ensaya una liberación muy humilde pero efectiva, porque cambia la praxis, las relaciones de sociabilidad y el proyecto de fondo para la sociedad y la Iglesia. (1975, p. 7)

Es aceptado por todos que han existido innumerables liberaciones parciales en la historia de la humanidad, pero, si estas son la anticipación o la garantía sobre una liberación universal, cabe la siguiente duda: ¿cuándo pueden ser las liberaciones parciales un anticipo de la liberación universal? ¿Cuándo la liberación universal no será solo un horizonte esperanzador sino que se convertirá en algo concreto y real para todos los que esperan? Para responder a esta cuestión, se desarrollará lo que Boff piensa sobre la evolución del hombre, ya que cada acto evolutivo es un acto-liberación y, en esta secuencia lógica, el hombre alcanzará la liberación universal:

Se puede ver todo el largo camino evolutivo del hombre como proceso de progresiva hominización. Hominización significa exactamente el proceso de tornarse hombre. Este se libera lentamente de sus orígenes animales, emerge en el claro-oscuro de la noosfera, supera el claro-oscuro del pensamiento salvaje, preso todavía en el mundo semiótico de las imágenes, rompe el pensamiento formal ligado a los conceptos, los supera por una formación simbólica cada vez más aguda y, por eso, libre de ambigüedades, construye el computador, y así va liberando cada vez más las capacidades de comunicación de los medios que le impiden su perfecta realización. El proceso está totalmente en apertura [...] En forma semejante, el proceso se efectuó en el relacionamiento del hombre con la naturaleza. Del estado primitivo de UNIÓN MÍSTICA con la naturaleza, la conciencia humana fue objetivando al mundo, comprendiéndolo, domesticándolo, sometiéndolo progresivamente a su proyecto histórico y, a su vez, haciéndose él cada vez más señor del mundo, hasta el punto de quererlo construir artificialmente [...] En verdad, la historia del proceso de liberación implica simultáneamente, con su correlativo, el proceso de opresión y dominación histórica del hombre. (1975, p. 49) 
Si la liberación universal se alcanza como un proceso, es decir, por medio de las liberaciones parciales tales como se menciona, entonces, el correlativo de opresión que acompaña a las liberaciones parciales podrá, seguramente, en este orden de ideas, acompañar a la liberación universal, de modo que es una opresión universal. Si a la liberación le acompaña la opresión, ¿cómo asegurar que la liberación de unos no será la opresión para otros?

Se debe recordar que Boff considera la libertad como una acción y proceso; el proceso actúa sobre las libertades ya alcanzadas en el sentido de que estas cuando ya no pueden continuar ofreciendo libertad se hace necesario reflexionar sobre ellas de forma crítica a fin de plantear nuevas libertades. En otras palabras, la libertad no es ya obtenida una vez para siempre, sino que es un siempre que obtiene.

Desde aquí, teniendo presente el pensamiento evolutivo, se comprende su relación con la liberación universal. Las sociedades han estado en una constante acción de proceso liberatorio, por ende, siguiendo en este proceso podrá llegar el momento en que se haya libertado todo lo que es dependiente, es decir, se dará la liberación universal y con ella la salvación. La liberación y la salvación se dan en la historia y no a pesar de ella (Boff, 1975, pp. 80-87). También es necesario comprender lo que para Boff puede ser llamado o no acción de liberación. Este filtro está en si la liberación busca cambiar el ethos opresivo del pensamiento moderno, ya que si esto no se cambia nada relevante se ha hecho y simplemente será una variación sobre la forma de opresión sin una liberación:

La modernidad optó por un sentido de ser y de vivir orientado por el saber y el poder de todo lo que se le ofrece, especialmente sobre el mundo, en términos de dominación, lucro y explotación. Toda revolución que no cambie este ethos cultural, que está en la base de nuestra historia occidental y también en el marxismo, será una variación sobre el mismo tema y no una verdadera liberación. Por lo menos no será la liberación buscada por los más serios grupos latinoamericanos de reflexión. (1987, pp. 24-25)

Cuando se indica que es necesario cambiar este ethos, se está pensando en el ethos del Reino de Dios, donde Dios dará justicia y amor para todos. La justicia la recibirán aquellos que sufrieron injusticia. Hacia este ethos es que debe apuntar toda liberación.

En esto se ve claramente la relación entre acción humana y el nuevo ethos o Reino de Dios; el esfuerzo humano que no tiene como horizonte el Reino de Dios no cambiará la raíz de la esclavitud, pero, si el Reino de Dios no se da con 
el esfuerzo humano, será algo de afuera que se imponga a la realidad humana, es decir, otra forma de dependencia. Entonces se considera que "el Reino no viene por arte de magia, sino como fruto del esfuerzo humano que ayuda a Dios a gestar el futuro definitivo. La salvación total no es algo que acontecerá cuando termine la historia, sino que se realiza dentro de un proceso de liberación" (Boff, 1987, p. 432). Para instaurar su Reino, Dios necesita al ser humano, ¿pierde el Reino de Dios la parte "de Dios" por necesitar ayuda del hombre"? ¿El Reino de Dios solo puede ser tal en las esferas divinas, pero en las humanas es un Reino más que puede o no ser acatado? ¿Qué es Reino de Dios y qué relación guarda con el hombre y su liberación?

\section{Reino de Dios y liberación}

Para Boff el Reino de Dios es

total y completa liberación de todo lo que aliena al hombre, desde las enfermedades y de la muerte, y hasta y especialmente el pecado. El Reino de Dios no puede ser reducido y privatizado a una dimensión del mundo. Es la totalidad global del mundo, que debe ser transformada en el sentido de Dios (1974, p. 244). Reino de Dios es la revolución y la transfiguración total, global y estructural de esta realidad, del hombre y del cosmos, purificados de todos los males y llenos de la presencia de Dios. El Reino de Dios no quiere ser otro mundo, sino el viejo mundo transformado en nuevo [...] Reino de Dios no significa solo la eliminación del pecado, sino de todo lo que el pecado significa para el hombre, para la sociedad y para el cosmos. En el Reino de Dios, el dolor, la ceguera, el hambre, las tempestades, el pecado y la muerte no se repetirán. $(1987$, p. 86)

Se entiende que el Reino de Dios no es un territorio aparte del mundo donde irán solo aquellos que probaron ser dignos de él, sino que implica un nuevo orden de las cosas en el mundo. Desde esta perspectiva, se puede considerar que el Reino de Dios representa la preocupación de Dios por la humanidad; se preocupa en el sentido de interesarse por ella, lo hace de tal forma que pretende cambiar las estructuras del mundo que no permiten la hominización del hombre. El hombre mismo se ha cerrado a Dios, y Dios mismo ha buscado al hombre en su Reino, para que este pueda vivir como quien realmente es, un ser abierto, unido y no confundido con Dios. 
El Reino de Dios no puede ser otro mundo o reducido a un espacio geográfico, puesto que, de ser así, ya no sería el Reino que liberará universalmente al hombre, sino sería otro Reino entre todos los reinos de este mundo y Dios simplemente sería Dios entre los dioses o monarcas que gobiernan. En su Reino, Dios sale y proclama "Yo soy la liberación total de todo mal y la liberación absoluta para el bien" (Boff, 1987, p. 257). El Reino de Dios representa la búsqueda por la realización plena del sentido de la realidad. Boff parte de Carl Jung para hablar de lo que representa el Reino de Dios.

El Reino de Dios no es tan solo una realidad espiritual, como luego pensarían algunos cristianos, sino una revolución global de las estructuras del mundo viejo. De ahí que él se presente como buena noticia para los pobres, luz para los ciegos, andar para los cojos, oído para los sordos, libertad para los encarcelados. (Boff, 1987, p. 257)

Sin embargo, se debe dejar claro que el Reino de Dios no evoluciona, sino que irrumpe. Este Reino no es prolongación orgánica del mundo presente tal como se encuentra en la historia, sino que es una irrupción (Boff, 1987, p. 258). Ya se había señalado que el Reino de Dios no es impositivo, sin embargo, al decir que este irrumpe, puede considerarse que realmente se trata de un Reino impositivo donde gobierna el monarca más poderoso de todos. Pero la irrupción no debe entenderse como si el Reino bajara de los cielos y se estableciera en una parte determinada, sino que debe ser entendida desde las acciones concretas que se llevan a cabo para la liberación y salvación universal.

En las liberaciones parciales y concretas, es donde irrumpe el Reino, pues allí es donde se vive la estructura crística, ${ }^{3}$ es decir, donde se busca la justicia, el amor, el perdón: ethos fundamental del Reino de Dios. El Reino universal irrumpe en las liberaciones particulares, ellas lo concretizan. "El Reino [...] está en íntima relación con el esfuerzo humano" (Boff, 1987, p. 264).

\subsection{Ethos del Reino de Dios}

Se podría resumir que la característica esencial del Reino de Dios es un Reino estructuralmente distinto en justicia de este mundo. Esto es posible por las siguientes premisas:

3 Ella preexistía dentro de la historia de la humanidad. Siempre que el hombre se abre a Dios y al otro, siempre que se realiza verdadero amor y superación del egoísmo, cuando el hombre busca justicia, solidaridad, reconciliación y perdón, ahí se da el verdadero cristianismo y emerge dentro la historia humana la estructura crística. 
El Reino de Dios abarca toda la realidad humana y cósmica que debe ser transfigurada y liberada de todo signo de alienación. Si el mundo sigue como está, no puede ser patria del Reino de Dios. Debe ser transformado en todas sus estructuras [...] es Dios quien intervendrá y sanará en su raíz la realidad total, transformando este mundo en un nuevo cielo y una nueva tierra. (Boff, 1987, p. 492)

El cambio de estructura no solo se dará en la vida social humana, puesto que, así como es necesario cambiar el ethos del mundo (transformar el corazón del hombre), también es necesario que el cambio se dé de manera cósmica. Como ya se vio, la vida corporal del hombre lo limita en la apertura total a Dios, por ello es necesario que este sea hominizado ${ }^{4}$ o plenificado por medio de su muerte. Entonces, si Dios solo cambia la estructura social del hombre y no cambia la posibilidad de que este tenga una apertura total con él, lo más probable es que el hombre vuelva a cerrarse sobre sí mismo; quiere esto decir que el hombre vuelva a vivir en pecado.

La estructura social que tiene a unos por amos y a otros por esclavos es consecuencia del pecado. Pecado es "cerrarse de sí mismo sobre sí mismo hasta excluir a Dios, es centrar el yo en sí mismo" (Boff, 1974, p. 208).

En resumidas cuentas, si Dios no hace un cambio estructural universal, su liberación será parcial y por ello el hombre no podrá alcanzar la salvación: para que el hombre pueda salvarse, Dios debe cambiar la estructura universal de la realidad. Es aquí donde tiene participación la praxis humana. Cabe recordar que es por medio de las acciones liberadoras que Dios irrumpe con su Reino, además, se añade que este tipo de praxis, sean hombres cristianos o no, viven en la estructura crística porque buscan la justicia, y esto es actuar según el designio de Dios. Además, la relación de Dios con el hombre se da en libertad:

Dios no hace nada si el hombre, en su libertad, no lo quiere; si se niega, seguirá siendo llamado a adherirse, pero no por la violencia, sino por el amor sacrificado: “Cuando sea levantado de la tierra atraeré a todos hacia mí (Jn 12, 32). (Boff, 1987, p. 363)

4 Se entiende por hominización cuando el hombre llega a tal comunión con Dios, y forma con él una unidad sin confusión, sin división y sin mutación. 


\subsection{El empobrecido}

Este cambio de ethos y de estructura que acontecerá con el Reino de Dios tiene a un sujeto específico al cual él privilegia, este es "el pobre". En primer lugar, ¿qué es ser "pobre"? ¿Y por qué son privilegiados? Para Boff existen dos clases de pobre, el pobre socioeconómico y el pobre evangélico. En lo referente al pobre económico, Boff considera que

es todo aquel que carece o está privado de los medios necesarios para la subsistencia (alimento, vestuario, habitación, salud básica, instrucción elemental y trabajo). Puede haber una pobreza inocente (tierras infecundas, sequías crónicas, etc.); mientras que hoy en día, esta pobreza las más de las veces, es mantenida por el sistema capitalista que obtiene de ella la mano de obra barata [...] Existe también una pobreza socioeconómica injusta porque está producida por un proceso de explotación del trabajo [...] El obrero no es pagado según la justicia, el precio de las materias primas es envilecido, los intereses de los préstamos necesarios para las cooperativas son exorbitantes. (Boff y Boff, 1986, p. 58)

La situación socioeconómica genera también pobreza concretizada en la discriminación de raza (negros), cultura (indígenas) y sexo (mujeres) (Boff y Boff, 1986, p. 59). El concepto de pobre económico hace referencia a un sujeto que ha sido empobrecido y, por ello, carece de lo necesario para la subsistencia. Aquí el pobre no es pobre esencialmente sino que lo hicieron pobre, es decir, la pobreza no es un estado espiritual de humildad sino una realidad con causas sociales concretas. La vida del pobre es absorbida por la vida del rico, por ello el pobre vive en muerte (carece de las necesidades básicas para la subsistencia). En cuanto al pobre evangélico, se señala que

es aquel que se hace disponible a Dios en la realización de su proyecto en este mundo y por eso se hace instrumento y señal del Reino de Dios. Por eso el pobre evangélico se muestra solidario con los pobres y se identifica con ellos como lo hizo Cristo. Es pobre evangélico en grado eminente, aunque no sea pobre socio-económico, por amor y solidaridad con los pobres socio-económicos se hace uno de ellos para luchar con ellos contra la pobreza injusta y buscar justa la liberación y la justicia. No magnifica ni la pobreza material, porque es resultado del pecado, ni la riqueza, que es expresión de la acumulación opresora y excluyente, sino que exalta y quiere la justicia social para todos. En el contexto del Tercer Mundo, no es pobre evangélico quien no se muestra 
solidario con la vida, la causa y las luchas de los pobres y de los oprimidos. (Boff y Boff, 1986, p. 60)

El concepto de pobre evangélico se puede referir a la decisión que toma un hombre por otro sujeto pobre; quien así decide está trabajando para el Reino de Dios. Esta persona se hace pobre en la solidaridad con el pobre, lucha con ellos y para ellos buscando la justicia. Por otro lado, el término evangélico puede ser aquí crítico con los evangélicos. Ser evangélico es ser alguien que busca la justicia del Reino de Dios, actuar en pro de hacer real dicha justicia para que aquellos que sufren injusticia reciban la justicia como recompensa. Entonces, ser evangélico es ser solidario con los pobres. Quien no actúa como pobre evangélico no es ni pobre ni mucho menos evangélico. Cristo fue un pobre evangélico porque fue solidario con los pobres. Todo cristiano debe ser un pobre evangélico o no puede ser llamado como tal.

\subsection{Razones del privilegio parcial del Reino de Dios}

Boff afirma que "la pobreza, en cuanto fruto de las relaciones injustas entre los hombres, provoca la intervención del Rey mesiánico, cuya primera función es hacer justicia al pobre y defender los derechos del débil” (1987, p. 30). El Mesías era la concreción de la esperanza en la intervención de Dios en favor del pueblo judío, quien tendría el espíritu de $\mathrm{YHVH}$ a fin de restaurar a Israel y darle tal gloria que las naciones vecinas verían su grandeza y acudirían a ellos. El rey mesiánico es el rey del Reino de Dios; en este caso puntual, es Jesús.

La función principal del rey mesiánico es hacer justicia al pobre y defenderlo. El pobre sufre injusticia y rechazo de una sociedad pecaminosa que se ha cerrado sobre sí misma y que no tiene como opción abrirse al otro prójimo empobrecido y sufriente. Como ya se ha visto, el Reino de Dios implica cambio de estructura y de ethos universal, por ende, quienes son humillados serán exaltados.

Lo anterior es fundamental para comprender por qué el pobre es privilegiado en el Reino de Dios. Este Reino traerá justicia y se la dará a quien ha carecido de ella; el Reino de Dios dará amor, amará a quienes han sido odiados. "Ellos son preferidos por Dios y por Cristo no porque sean buenos sino porque son pobres y sufren injusticias. Dios no quiere la pobreza bajo la cual padecen" (Boff y Boff, 1986, p. 59). Por los pobres comenzará el Reino de Dios, se les restituirá la justicia y el derecho de los que han sido privados (Boff, 1978b, p. 46). Siguiendo a Joachim Jeremias, Boff amplía su comprensión del término pobre. 
Los pobres son los oprimidos en sentido amplísimo, los que sufren opresión y no se pueden defender, los sin esperanza, los que no tienen salvación... Todos los que padecen alguna necesidad, los hambrientos, los sedientos, los sin vestido, los forasteros, los enfermos, los presos, los perdidos y los pecadores. (1987, p. 310)

Se podría indicar que en las reflexiones anteriores ya se ha aludido indirectamente a todos los aquí mencionados, pero uno de ellos no ha sido pensado, el pecador, pues pensar en él podría ser contradictorio. El pecador, en esta perspectiva, también es un pobre y como pobre será privilegiado en el Reino de Dios; como privilegiado será salvo. Ya se señaló que la estructura de este mundo es de pecado y que hay pobres como consecuencia de este, por ello, ¿cómo puede el pecador que, al parecer ha causado que el pobre sea pobre, ser él mismo un pobre?

Para Boff el pecado es "la tentativa absurda, por imposible, de hacer uno mismo, de querer ser lo que el hombre jamás puede ser: fundamento de sí mismo, absolutamente independiente, creador de sí mismo" (1987, p. 434). Esta clase de pecado tiene como consecuencia hacer al pobre lo que es. A este pecador se le exige conversión. El pecador que es visto como marginado y como pobre es el que ha sido rechazado por un sistema religioso autosuficiente, que ha establecido unos principios ortodoxos que dictaminan lo que es o no religioso. Aquí, los fariseos son un buen ejemplo, pues ellos colocaban cargas con su ortodoxia a las personas, entonces quienes no cumplían con esta ortodoxia eran rechazados. Por ello es que ser ciego, desde el pensamiento fariseo, correspondía a un pecado del enfermo o de su familia (Jn 9, 1-41), por tal razón se le rechazaba. Es de esta clase de pecadores de los que se están hablando. En este orden de ideas, se afirma, entonces, que los publicanos y las rameras se salvarán primero que un fariseo.

¿Por qué? Por su situación de marginados del sistema socio-religioso judaico son más aptos para oír y seguir el mensaje de Jesús. Ellos no tienen nada que perder, pues nada tienen o nada son socialmente. Solo deben esperar. El fariseo no. Vive estructurado en el sistema que creó para sí: es rico, tiene fama, tiene religión y está seguro de que Dios está de su lado. (Boff, 1974, p. 89)

El pobre es privilegiado por Dios simplemente porque es él quien carece de todo lo que ofrece el Reino de Dios: amor, misericordia, justicia, perdón, felicidad, etc. La pobreza no es vista como un sujeto sintetizador y legitimador de lo que es la teología, tampoco es una vida que se debe buscar para pretender estar más cerca de Dios. Antes bien, la pobreza se da por consecuencia de un pecado 
estructural y social, y como Dios está para salvar, entonces salvará a quienes sufren la consecuencia del pecado.

A quienes son pecadores, es decir, los que empobrecen y se cierran sobre sí llegando a la imposibilidad de amar sin egoísmo, se les exigirá la conversión, que se abran a Dios a través del prójimo si pretenden salvarse, pues, si en toda la vida se cerraron en sí mismos, en la muerte cuando se elige la plena apertura o cerrazón, es lógico que ellos estarán imposibilitados de optar por Dios porque no conocieron esto en vida. "Desde que Dios se hizo hombre toda conversión a Dios y a Cristo implica también una conversión al hombre. Violar al hombre y su situación vital es violar, si no destruir, la presencia de Dios en ellos" (Boff, 1975, p. 64)

\subsection{Realización del Reino de Dios}

La perspectiva del Reino de Dios deja, como siempre que se pretende hablar de él, la pregunta por el "cuándo" se realizará: ¿en el tiempo presente?, ¿en el futuro, al final de la historia?, ¿o ya aconteció y "cuándo"? Desde Boff se contestaría que el Reino se da en el presente, se dará en el futuro y ya se dio en el pasado. ¿Cómo entender el Reino desde estas tres afirmaciones?

La perspectiva escatológica de Boff se orienta, en cuanto al Reino de Dios $\mathrm{y}$, por ende, a la salvación, en la realización de la esperanza del ser humano en este tiempo. Es decir, la salvación se da ahora mismo. Ya se ha hablado de las liberaciones parciales por las cuales Dios y su Reino se hacen presentes; también esto puede entenderse desde el vivir en la estructura crística: quien busca justicia, misericordia y amor está actuando no solo en la voluntad de Dios, sino que asimismo está anticipando el Reino. El Reino se da ya mismo. La escatología habla del presente en función del futuro, aquí se experimenta el bien, la gracia, etc., en forma imperfecta (1978a, p. 130).

A este ya mismo del Reino se le debe agregar un "todavía no". El Reino no se ha realizado plenamente, aunque el Reino se hace concreto en las liberaciones parciales, ninguna de estas liberaciones es el Reino en su totalidad. El Reino de Dios irrumpirá absoluto en un futuro, donde todo lo que se ha experimentado actualmente de forma imperfecta será vivido de forma perfecta; el hombre será plenificado y hominizado. La escatología no se inaugura solo al fin del mundo; ella se da ya en el presente, se modela en los hechos históricos y se va procesando en las ambigüedades del tempus medium hasta llegar a su plenitud en Dios (1975, p. 168).

Por último, cuando se afirma que el Reino ya se dio en el pasado, se está pensando en Jesús. Él predicó que el Reino de los cielos se había acercado; su ministerio demostró que el Reino ya estaba en medio de los hombres, sus milagros 
son signos de la presencia del Reino (Boff, 1978b, p. 26). La liberación buscada por Jesús puede ser entendida como las liberaciones parciales buscadas por los hombres, entonces, así como se dijo que Dios irrumpe en ellas, también se dice que Dios y su Reino aparecieron en la vida y ministerio de Jesús.

A la pregunta de Juan Bautista encarcelado: “¿Eres tú el que ha de venir, o debemos esperar por otro?", responde Jesús: "los ciegos ven y los cojos andan, los leprosos quedan limpios y los sordos oyen, los muertos resucitan y se anuncia a los pobres la Buena Nueva" (Mt 11,3, 5). Aquí está el signo de un cambio total de la situación [...] Cristo se entiende como el Liberador porque predica, presencializa y ya está inaugurando el Reino de Dios. (Boff, 1987, p. 68)

\section{Conclusión}

Buscar la liberación es participar en la salvación, el hombre a través de su historia ha estado en proceso evolutivo de liberación, que ciertamente es concreta, pero a su vez participa en la salvación universal. Para comprender la relación que se da entre liberaciones concretas y salvación universal, es necesario pensar tal relación desde el Reino de Dios, porque ahí se da la unión entre las liberaciones particulares como la salvación universal del hombre en el propósito de Dios. Dios en su Reino efectuará un cambio de estructura universal que permita la salvación del hombre, también ha de cambiar el corazón del hombre para que este se abra a él y así se alcance su plena realización: la hominización. "El Reino significa la totalidad del mundo material, espiritual y humano liberado ya de todo lo que lo estigmatiza e introducido en el orden nuevo de Dios" (Boff, 1987, pp. 553-554).

La situación triste y ambigua de este mundo pecador conocerá un día su fin; un día, Dios se apiadará de los hombres y los liberará de todos los elementos alienantes. Reino de Dios es la expresión simbólica de esta verdad trascendental [...] la realidad de este mundo tiene un sentido último y que puede ser perfeccionada por Dios, y solo por él. (Boff, 1987, p. 91) 


\section{Referencias}

Boff, L. (1974). Jesucristo el liberador: ensayo de cristología crítica para nuestro tiempo. Buenos Aires, Argentina: Latinoamérica Libros.

Boff, L. (1975). Teología desde el cautiverio. Bogotá, Colombia: Indo-American Press Service.

Boff, L. (1978a). Hablemos de la otra vida. Santander, España: Sal Terrae.

Boff, L. (1978b). Jesucristo y nuestro futuro de liberación. Bogotá, Colombia: Indo-American Press Seervice.

Boff, L. (1987). Jesucristo y la liberación del hombre. Madrid, España: Cristiandad.

Boff, L. y Boff, C. (1986). Cómo hacer teología de la liberación. Bogotá, Colombia: Paulinas. 